\title{
The impact of Aloe vera and licorice extracts on selected mechanisms of humoral and cell-mediated immunity in pigeons experimentally infected with PPMV-1
}

Daria Dziewulska* ${ }^{*}$, Tomasz Stenzel, Marcin Śmiałek, Bartłomiej Tykałowski and Andrzej Koncicki

\begin{abstract}
Background: The aim of the study was to evaluate the impact of herbal extracts on selected immunity mechanisms in clinically healthy pigeons and pigeons inoculated with the pigeon paramyxovirus type 1 (PPMV-1). For the first 7 days post-inoculation (dpi), an aqueous solution of Aloe vera or licorice extract was administered daily at 300 or $500 \mathrm{mg} / \mathrm{kg}$ body weight (BW). The birds were euthanized at 4, 7 and $14 \mathrm{dpi}$, and spleen samples were collected during necropsy. Mononuclear cells were isolated from spleen samples and divided into two parts: one part was used to determine the percentage of $\operatorname{lgM}^{+} \mathrm{B}$ cells in a flow cytometric analysis, and the other was used to evaluate the expression of genes encoding IFN- $\gamma$ and surface receptors on $\mathrm{CD}^{+}, \mathrm{CD}^{+}$and $\mathrm{CD} 8^{+} \mathrm{T}$ cells.

Results: The expression of the IFN- $\gamma$ gene increased in all birds inoculated with PPMV-1 and receiving both herbal extracts. The expression of the CD3 gene was lowest at $14 \mathrm{dpi}$ in healthy birds and at $7 \mathrm{dpi}$ in inoculated pigeons. The expression of the CD4 gene was higher in uninoculated pigeons receiving both herbal extracts than in the control group throughout nearly the entire experiment with a peak at $7 \mathrm{dpi}$. A reverse trend was observed in pigeons inoculated with PPMV-1 and receiving both herbal extracts. In uninoculated birds, increased expression of the CD8 gene was noted in the pigeons receiving a lower dose of the Aloe vera extract and both doses of licorice extracts. No significant differences in the expression of this gene were found between inoculated pigeons receiving both herbal extracts. The percentage of $\operatorname{lgM}^{+} \mathrm{B}$ cells did not differ between any of the evaluated groups.

Conclusions: This results indicate that Aloe vera and licorice extracts have immunomodulatory properties and can be used successfully to prevent viral diseases, enhance immunity and as supplementary treatment for viral diseases in pigeons.
\end{abstract}

Keywords: Aloe vera, Flow cytometry, Gene expression, Herbal extracts, Licorice, Pigeons, PPMV-1

\footnotetext{
* Correspondence: daria.pestka@uwm.edu.pl

Department of Poultry Diseases, Faculty of Veterinary Medicine, University of

Warmia and Mazury in Olsztyn, ul. Oczapowskiego 13/14, 10-719 Olsztyn,

Poland
}

(c) The Author(s). 2018 Open Access This article is distributed under the terms of the Creative Commons Attribution 4.0 International License (http://creativecommons.org/licenses/by/4.0/), which permits unrestricted use, distribution, and reproduction in any medium, provided you give appropriate credit to the original author(s) and the source, provide a link to the Creative Commons license, and indicate if changes were made. The Creative Commons Public Domain Dedication waiver (http://creativecommons.org/publicdomain/zero/1.0/) applies to the data made available in this article, unless otherwise stated. 


\section{Background}

Immunomodulation is the stimulation or suppression of immune responses in living organisms. Numerous substances, both natural and synthetic, exert effects on immunity. Natural immunomodulators include herbal preparations whose popularity continues to increase due to the decreasing effectiveness of antibiotics and other synthetic drugs [27].

The therapeutic properties of Aloe vera, also known as Barbados aloe (Aloe barbadensis Miller), have been recognized already in ancient times. Aloe vera is a succulent plant of the lily family (Liliaceae) [6]. The part of Aloe vera plants that plays the most important role in natural medicine are its leaves which are a rich source of latex and gel containing $98.5 \%$ to $99.5 \%$ water and 75 biologically active compounds [9]. Aloe vera gel also contains polysaccharides, including acemannan which is one of the most potent plant-derived immunomodulators. Acemannan binds to macrophage receptors and stimulates the synthesis of cytokines (interleukin 1 (IL-1), interleukin 6 (IL-6)) and tumor necrosis factor-alpha (TNF- $\alpha)[8,11]$. Aloe vera extract could also stimulate cell-mediated immunity (CMI). Vahedi et al. (2011) reported a higher percentage of $\mathrm{CD} 4^{+}$and $\mathrm{CD} 8^{+} \mathrm{T}$ cells in the peripheral blood of rabbits receiving Aloe vera extract [43]. Aloe vera extracts were also found to stimulate humoral immunity in chickens experimentally infected with the Newcastle disease virus (NDV) [26]. The discussed plant delivers numerous health benefits and exerts anti-inflammatory, antibacterial, antifungal and anti-carcinogenic effects due to the presence of anthraquinones, saccharides and antioxidant vitamins (A, $\mathrm{C}$ and E) [38].

Licorice (Glycyrrhiza glabra) is also a popular medicinal plant of the legume family (Fabaceae). It is valued mostly for its roots which contain $1 \%$ to $9 \%$ glycyrrhizic acid (glycyrrhizin) [15]. Glycyrrhizin is a potent immunomodulator which stimulates the production of interferon $[1,42]$ and the proliferation of regulatory (Treg) cells in mice [16]. Licorice extracts have been found to increase the phagocytic capacity of chicken granulocytes and mononuclear cells [12]. Similarly to Aloe vera, licorice exerts various types of antiviral activity. Licorice inhibits viral replication not only by becoming attached to the cell membrane and compromising the cells' ability to undergo endocytosis, which prevents the virus from penetrating cells [46], but also by activating the NF- $\mathrm{kB}$ protein complex which plays a key role in regulating the immune response to infections and stimulates IL- 8 secretion [34].

Medicinal herbs are widely used as functional additives in animal diets to improve the palatability and digestibility of feed [4, 21]. Herbal functional additives have various properties and can be used in the prevention and supplementary treatment of infectious diseases with different etiology. These properties can be directly attributed to herbal extracts' ability to stimulate immune responses, which was observed in chickens [9]. For example, Liu et al. (2010) demonstrated that the addition of four herbal extracts, Astragalus membranaceus, Codonopsis pilosula, Epimedium spp. and Glycyrrhiza uralensis, to drinking water can enhance the immune response in immunosuppressed chickens with the reticuloendotheliosis virus [23]. Further evidence of the immunomodulatory effects of herbal extracts was provided by Latheef et al. (2017) who reported that Withania somnifera, Tinospora cordifolia and Azadirachta indica were capable of inhibiting the replication of the chicken infectious anemia virus and increasing the cell-mediated response of chickens against this virus [22]. However, the immunomodulatory effects of herbal extracts have never been investigated in domestic pigeons.

Viral diseases, in particular infections with the pigeon circovirus (PiCV) which exerts immunosuppressive effects, pose a serious problem in pigeon breeding [36]. Since a laboratory protocol for culturing PiCV under laboratory conditions has not been developed to date [10], the pigeon paramyxovirus type 1 (PPMV-1), the pigeon variant of NDV, is successfully used for experimental inoculation of pigeons [13, 28, 37, 39].

The course of an NDV infection can differ substantially, depending on the strain's virulence [28]. Strain virulence also determines birds' immune responses to infection or inoculation with live vaccines. The early immune response to a viral infection is influenced by innate immunity, a universal mechanism that protects living organisms against infections. Innate immunity relies on pattern recognition receptors (PRRs) which identify pathogen-associated molecular patterns (PAMPs). PRRs enable an organism to discriminate between nonself and self antigens. Toll-like receptors (TLRs) are a group of PRRs which play a key role in the initiation of immune responses [40]. TLRs are found on the surface of selected immune system cells, such as lymphocytes, heterophils and macrophages, and their stimulation constitutes a signal that activates non-specific and specific immune responses. In an in vitro study, the inoculation of chicken peripheral blood heterophils and mononuclear cells with NDV stimulated the production of interferon and nitric oxide (NO) [2]. Research has also demonstrated that the expression of genes encoding interferon $\alpha$ (IFN- $\alpha)$, IFN- $\beta$, IL-1 $\beta$ and IL- 6 increased in chicken splenocytes inoculated with NDV [32]. However, the observed increase in expression was determined by the NDV strain and its virulence, and it was not induced by mild viral strains $[20,24]$.

Cell-mediated immunity associated with T cells, including cytokine-producing $\mathrm{CD}^{+}$lymphocytes and cytotoxic 
$\mathrm{CD}^{+}$lymphocytes (CTL), also plays an important role in the immune response to NDV. In chickens, a CMI response to NDV was observed already 2-3 days after inoculation with the vaccine virus strain [31]. Similarly to the innate immune response, the adaptive immune response is influenced by several factors, including strain virulence [30] and the breed of chickens exposed to vaccine and field isolates [7]. The humoral immune response, which involves the proliferation of $\mathrm{B}$ cells and the production of immunoglobulins $\mathrm{M}, \mathrm{Y}$ and A (IgM, IgY, IgA), is also an important element of immunity against NDV [19]. Anti-NDV antibodies are detected in mucosal membranes of the upper respiratory tract and in blood already 6 days after infection or inoculation with an attenuated vaccine, and their concentrations peak 2128 days after infection. The antibodies' role is to neutralize the virus by binding to it and preventing it from adhering to host cells [3].

The influence of paramyxovirus infections on the immune response in birds has been studied extensively [19, $20,24,32]$. However, very little is known about the influence of immunomodulatory herbal extracts on viral infections and immune responses in infected birds. A few studies have been conducted to investigate the immunomodulatory effects of Aloe vera and licorice extracts on birds infected with the avian paramyxovirus serotype-1 (APMV-1), and their results are limited to analyses of antibodies against this virus in chickens [26].

In view of alternative immunomodulation-based strategies and the scarcity of published information relating to the applicability of immunomodulatory herbal extracts in pigeons, the main aim of this basic research was to determine the influence of Aloe vera and licorice extracts on selected mechanisms of cell-mediated and humoral immunity in virus-inoculated pigeons. PPMV-1 was used as an experimental model because it is easy to culture under laboratory conditions. However, it should be noted that Newcastle disease is a notifiable disease that has to be legally reported to the authorities, and treatment of PPMV-1 infections in pigeons is not allowed.

\section{Methods}

\section{Virus}

Pigeons were infected with the pigeon paramyxovirus serotype-1 (PPMV-1/pigeon/Poland/AR3/95) obtained from the National Veterinary Research Institute in Puławy. The pathogenicity of the applied isolate was classified based on biological (calculation of the Intracerebral Pathogenicity Index (ICPI) for one-day-old SPF chickens) and molecular analyses (analysis of the amino acid sequence at the cleavage site in the fusion protein). The ICPI was 1.4, and the amino acid sequence at the cleavage site in the fusion protein was ${ }^{112} \mathrm{R}-\mathrm{R}-\mathrm{Q}-\mathrm{K}-\mathrm{R}-$
$\mathrm{F}^{117}$. Based on those results, the virus was classified as a mesogenic pathotype.

\section{Plant extracts \\ Aloe vera}

The Aloe vera extract was obtained by freeze/spray drying of aloe leaf juice. Five grams of the extract with maximum moisture content of $8 \%$ and bulk density of $0.3-0$. $6 \mathrm{~g} / 1 \mathrm{ml}$ were obtained from $1000 \mathrm{~g}$ of fresh Aloe vera juice.

\section{Licorice}

Dry licorice extract was obtained by spray drying an aqueous solution of licorice root, a registered feed additive (European Union Register of Feed Additives, group 2b: natural products - botanically defined: CAS 6891691-6 FEMA 2629, CoE 218, pursuant to Regulation (EC) No 1831/2003). The extract contained 20\% glycyrrhizic acid, and it was characterized by maximum moisture content of $3.6 \%$ and bulk density of $0.5 \mathrm{~g} / 1 \mathrm{ml}$.

Aloe vera and licorice extracts were free of pathogenic bacteria such as Escherichia coli, Staphylococcus aureus and Pseudomonas aeruginosa in $10 \mathrm{~g}$ of the product. The contamination of the extract with selected pathogenic bacteria (Escherichia coli, Staphylococcus aureus and Pseudomonas aeruginosa) was determined in accordance with PN-EN ISO 6887-1 [29]. First, a 10\% solution of the extract was prepared in the amount of $100 \mathrm{~mL}$ (conc. $10^{-1}$ ), and it was used as the initial suspension that was diluted ten-fold to obtain a concentration of $10^{-5}$. Using a sterile pipette, $1 \mathrm{~mL}$ of the sample from each dilution was transferred to the following culture media: MacConkey Agar No. 3, Columbia Agar with sheep blood plus and Mannitol salt agar. All culture media were obtained from the same manufacturer (Oxoid, UK), and all analyses were conducted in duplicate. The suspension was spread evenly with a sterile cell spreader, and the plates were incubated at a temperature of $37{ }^{\circ} \mathrm{C}$ for $24 \mathrm{~h}$. Beginning with the first dilution, an increase in the CFU of the tested pathogenic bacteria was not observed on any of the plates after incubation.

\section{Pigeons}

One hundred twenty 8-week-old fantail pigeons were obtained from a private breeder. The flock in the breeding facility had not been vaccinated against PPMV-1 since 2008, and it was free of the infection. Before the experiment, cloacal swabs and blood samples were collected from all birds to rule out PPMV-1 infection with the use of the real-time PCR method described by Wise et al. (2004) and modified by Cattoli et al. (2009) and to determine the presence of antibodies against PPMV-1 with the use of the commercial ELISA test kit (IDEXX, USA) according to the method 
described by Stenzel et al. (2011) [5, 35, 45]. The birds were housed in isolated units in a PCL3 biosafety facility of the Department of Poultry Diseases, Faculty of Veterinary Medicine of the University of Warmia and Mazury in Olsztyn. The biosafety facility is equipped with a HEPA filtering system and an automated system for pressure control in corridors, bird units and hygiene stations to prevent contamination of experimental premises. Every group of pigeons was housed in a separate unit. The birds were administered seed mixtures and water ad libitum throughout the experiment.

\section{Experimental design}

Pigeons were divided into 10 groups of 12 birds each. Pigeons from groups A1, B1, C1, D1 and K1 were inoculated oculonasally with $10^{6} \mathrm{EID}_{50}$ of PPMV-1 at $100 \mu \mathrm{L}$ per bird (applied to the nostril and the eye at $50 \mu \mathrm{L}$ each). For the first 7 days post-inoculation (dpi), an aqueous solution of Aloe vera extract was administered daily per os at $300 \mathrm{mg} / \mathrm{kg}$ body weight (BW) (groups A and A1) or $500 \mathrm{mg} / \mathrm{kg} \mathrm{BW}$ (groups B and B1), and an aqueous solution of licorice extract was administered at $300 \mathrm{mg} / \mathrm{kg} \mathrm{BW}$ (group C, C1) or $500 \mathrm{mg} / \mathrm{kg} \mathrm{BW}$ (group $\mathrm{D}, \mathrm{D} 1)$. Control group ( $\mathrm{K}$ and $\mathrm{K} 1$ ) birds were orally administered $0.9 \% \mathrm{NaCl}$. At 4,7 and $14 \mathrm{dpi}$, the birds were euthanized by intravenous administration of pentobarbital sodium at $70 \mathrm{mg} / 1 \mathrm{~kg} \mathrm{BW}$ (Morbital, Biowet Puławy, Poland) after premedication by intramuscular injection of butorphanol tartrate at $4 \mathrm{mg} / 1 \mathrm{~kg} \mathrm{BW}$ (Torbugesic, Zoetis, USA), and spleen samples were collected during an anatomopathological examination (Table 1). Mononuclear cells were isolated from spleen samples and divided into two parts: one part was used to determine the percentage of $\operatorname{IgM}^{+} \mathrm{B}$ cells in a flow cytometric analysis, and the other was used in RNA extraction to evaluate the expression of genes encoding IFN $-\gamma$ and surface receptors on $\mathrm{CD}^{+}, \mathrm{CD}^{+}$and $\mathrm{CD} 8^{+} \mathrm{T}$ cells.

\section{Isolation of mononuclear cells}

Mononuclear cells were isolated from whole spleens using the manual Dounce tissue grinder (Kimble, USA) in $9 \mathrm{ml}$ of a complete growth medium (RPMI - 1640, $10 \%$ fetal bovine serum (FBS), 1\% MEM non-essential amino acids solution, $1 \%$ penicillin - streptomycin, $1 \%$ HEPES, $1 \%$ sodium pyruvate) (Sigma Aldrich, USA) and were filtered (70 $\mu \mathrm{m}$ mesh). A homogenous suspension was obtained, and centrifuged cell pellets ( $450 \mathrm{~g}$ for $10 \mathrm{~min}$ at $25^{\circ} \mathrm{C}$ ) were resuspended in $2.3 \mathrm{~mL}$ of a complete growth medium and gently layered on $2.5 \mathrm{~mL}$ of Histopaque-1077 (Sigma Aldrich, USA). After centrifugation (30 min, $400 \mathrm{~g}$, at room temperature), the upper layer of the opaque interface containing mononuclear cells was carefully aspirated. Finally, the obtained mononuclear cells were washed twice and resuspended in $1 \mathrm{~mL}$ of PBS (phosphate-buffered saline) (Sigma Aldrich, USA). Cell concentrations and the percentage of viable cells were determined in the Vi-cell XR analyzer (Beckman Coulter, USA).

\section{Flow cytometry}

Before the experiment, the cross-reactivity of Goat antiChicken IgM-FITC polyclonal antibodies (AbD Serotec, UK) was checked in pigeon lymphocytes. For this purpose, mononuclear cells were isolated from the thymus, bursa of Fabricius and peripheral blood. The antibodies' crossreactivity was characterized by $3.99 \%, 44.46 \%$ and $9.5 \%$ of $\mathrm{IgM}^{+} \mathrm{B}$ cells isolated from the thymus, bursa of Fabricius and peripheral blood, respectively. The quantity of the tested antibodies ( $3 \mu \mathrm{g}$ antibodies per one million cells) was determined experimentally in serial dilutions ( 1 to $5 \mu \mathrm{g}$ antibodies per one million cells).

Thereafter, half a million mononuclear cells isolated from spleen samples were stained with $1.5 \mu \mathrm{g}$ of the $\operatorname{IgM}^{+}$ polyclonal antibody for B cells. The samples were incubated in darkness on ice for $30 \mathrm{~min}$. Next, the cells were twice rinsed in PBS, centrifuged at $400 \mathrm{~g}$ for $10 \mathrm{~min}$,

Table 1 Experimental design

\begin{tabular}{|c|c|c|c|c|}
\hline \multirow[t]{3}{*}{ Group } & \multicolumn{4}{|l|}{ Day of experiment } \\
\hline & \multirow[t]{2}{*}{$1-7$} & 8 & $9-15$ & \multirow[t]{2}{*}{22} \\
\hline & & Experimental inoculation with PPMV-1, $10^{6} \mathrm{EID}_{50}$ & Once daily administration of: & \\
\hline A & \multirow[t]{10}{*}{ Adaptation to new conditions } & - & Aloe vera, $300 \mathrm{mg} / \mathrm{kg} \mathrm{BW}$ & \multirow{10}{*}{$\begin{array}{l}\text { Collection of spleen samples } \\
\text { for molecular biology and } \\
\text { flow cytometry analyses }\end{array}$} \\
\hline $\mathrm{A} 1$ & & + & & \\
\hline B & & - & Aloe vera, $500 \mathrm{mg} / \mathrm{kg} \mathrm{BW}$ & \\
\hline B1 & & + & & \\
\hline C & & - & licorice, 300 mg/kg BW & \\
\hline C1 & & + & & \\
\hline D & & - & licorice, 500 mg/kg BW & \\
\hline D1 & & + & & \\
\hline K & & - & $0.9 \% \mathrm{NaCL}$ & \\
\hline K1 & & + & & \\
\hline
\end{tabular}


and the resulting pellets were suspended in $400 \mu \mathrm{L}$ of PBS and analyzed with the use of the FACS Canto II (BD, USA) flow cytometer. Data were acquired in FACS Diva Software 6.1.3. (BD, USA). Cells were analyzed and immunophenotyped in FloJo 7.5.5 (Tree Star, USA).

\section{Real-time PCR}

The number of mononuclear cells isolated from spleen samples was standardized to $5 \times 10^{6}$ and used for RNA isolation with the use of the RNeasy Mini Kit (Qiagen, Germany) according to the manufacturer's protocol. Genomic DNA remaining in the samples after RNA isolation was digested with deoxyribonuclease I (Sigma Aldrich, USA). RNA quality was evaluated in the 2100 Bioanalyzer (Agilent, USA). The concentrations of eluted RNA were measured with the NanoDrop 2000 spectrophotometer (Thermo Fisher Scientific, USA), and the samples were stored at $-80{ }^{\circ} \mathrm{C}$ until further analysis.

Reverse transcription was carried out with the HighCapacity cDNA Reverse Transcription Kit (Life Technologies, USA) according to the manufacturer's recommendations. The concentration of RNA for the synthesis of complementary DNA (cDNA) was standardized to 0 . $5 \mu \mathrm{g}$ per sample. The expression of the gene encoding IFN- $\gamma$ and the genes encoding receptors on the surface of $\mathrm{T}$ cells (CD3, CD4 and CD8) was determined by realtime PCR. The reaction mixture for all analyzed genes had the following composition: $10 \mu \mathrm{L}$ of the Power SYBR $^{\circ}$ Green PCR Master Mix (Life Technologies, USA), $1.8 \mu \mathrm{L}$ of each $10 \mu \mathrm{M}$ primer, $4.4 \mu \mathrm{L}$ of RNase-free water, and $2 \mu \mathrm{L}$ of cDNA. The primer sequences and the accession numbers of gene sequences used for designing the primers are presented in Table 2. The reaction was carried out under the following conditions: polymerase activation at $95{ }^{\circ} \mathrm{C}$ for $10 \mathrm{~min}$, followed by 40 two-stage cycles: denaturation at $95{ }^{\circ} \mathrm{C}$ for $30 \mathrm{~min}$, primer annealing and chain elongation at $60{ }^{\circ} \mathrm{C}$ for $60 \mathrm{~s}$. The relative expression of each gene was calculated using the $2^{-\Delta \Delta C t}$ method [25] normalized to efficiency corrections, expression levels of reference gene coding glyceraldehyde 3-phosphate dehydrogenase (GAPDH) and reference groups (K and K1) in GenEx 6.1.0.757 data analysis software (MultiD, Sweden).

\section{Statistical analysis}

The significance of differences between the relative expression of IFN- $y, C D 3, C D 4$ and CD8 genes and the percentage of $\operatorname{IgM}^{+} \mathrm{B}$ cells were analyzed using the Kruskal-Wallis non-parametric test for independent samples. The analyzed factors were the experimental group and the day of the experiment. Differences were considered significant at a confidence level of 95\% $(P<0.05)$.

\section{Results}

\section{Expression of the IFN- $\gamma$ gene}

No significant differences in the expression of the gene encoding IFN-y in mononuclear cells isolated from spleen samples were observed between the experimental groups during the experiment. The expression of the above gene was higher in groups $\mathrm{A}$ and $\mathrm{C}$ at 4 and 14 $\mathrm{dpi}$, and in groups B and D at 4 dpi than in control group $\mathrm{K}$ (expression level $>1$ ). In birds uninfected with PPMV-1, the lowest levels of IFN- $\gamma$ gene expression were noted at $7 \mathrm{dpi}$ (Fig. 1). In all inoculated birds receiving herbal extracts, the expression of the IFN- $\gamma$ gene was higher than in control group $\mathrm{K} 1$ at 4, 7 and $14 \mathrm{dpi}$ (Fig. 2).

\section{Expression of the $\mathrm{CD} 3$ gene}

The expression of the gene encoding surface receptor CD3 in the mononuclear cells of group A and D birds at 4 and $7 \mathrm{dpi}$ and group $\mathrm{C}$ birds at $7 \mathrm{dpi}$ was higher than in the control group. In group B, the expression of the analyzed gene did not increase relative to group $\mathrm{K}$ throughout the experiment, and it was significantly lower than in group D at 4 and $7 \mathrm{dpi}(P=0.023$ and $P=0.045$, respectively) (Fig. 1). The expression of the CD3 gene was higher

Table 2 Primers used for real time PCR

\begin{tabular}{|c|c|c|c|}
\hline Primer & Sequence $5^{\prime}->3^{\prime}$ & Fragment size (bp) & Accession number \\
\hline CD3 F & GCAATTACGATGATCCCAGAG & 112 & XM_005500716.2 \\
\hline CD3 R & GCGTCCACTTCAATGCAATTC & & \\
\hline CD4 F & GAACGTGTGAATGGGACTCAGA & 116 & MG214789 \\
\hline CD4 R & GTCATTGTCTTCTATGAGGTGACA & & \\
\hline CD8 F & TTCATCTGGGTTCCCTTGGCA & 97 & MG214790 \\
\hline CD8 R & CTGCATCTTCGGCTCCTGGT & & \\
\hline IFNY F & CTGACAAGTCAAAGCCGCAC & 125 & DQ479967.1 \\
\hline IFNY R & AGTCATTCATCT GAAGCTTGGC & & \\
\hline GAPDH F & CCCTGAGCTCAATGGGAAGC & 137 & NM_001282835.1 \\
\hline GAPDH R & TCAGCAGCAGCCTTCACTAC & & \\
\hline
\end{tabular}



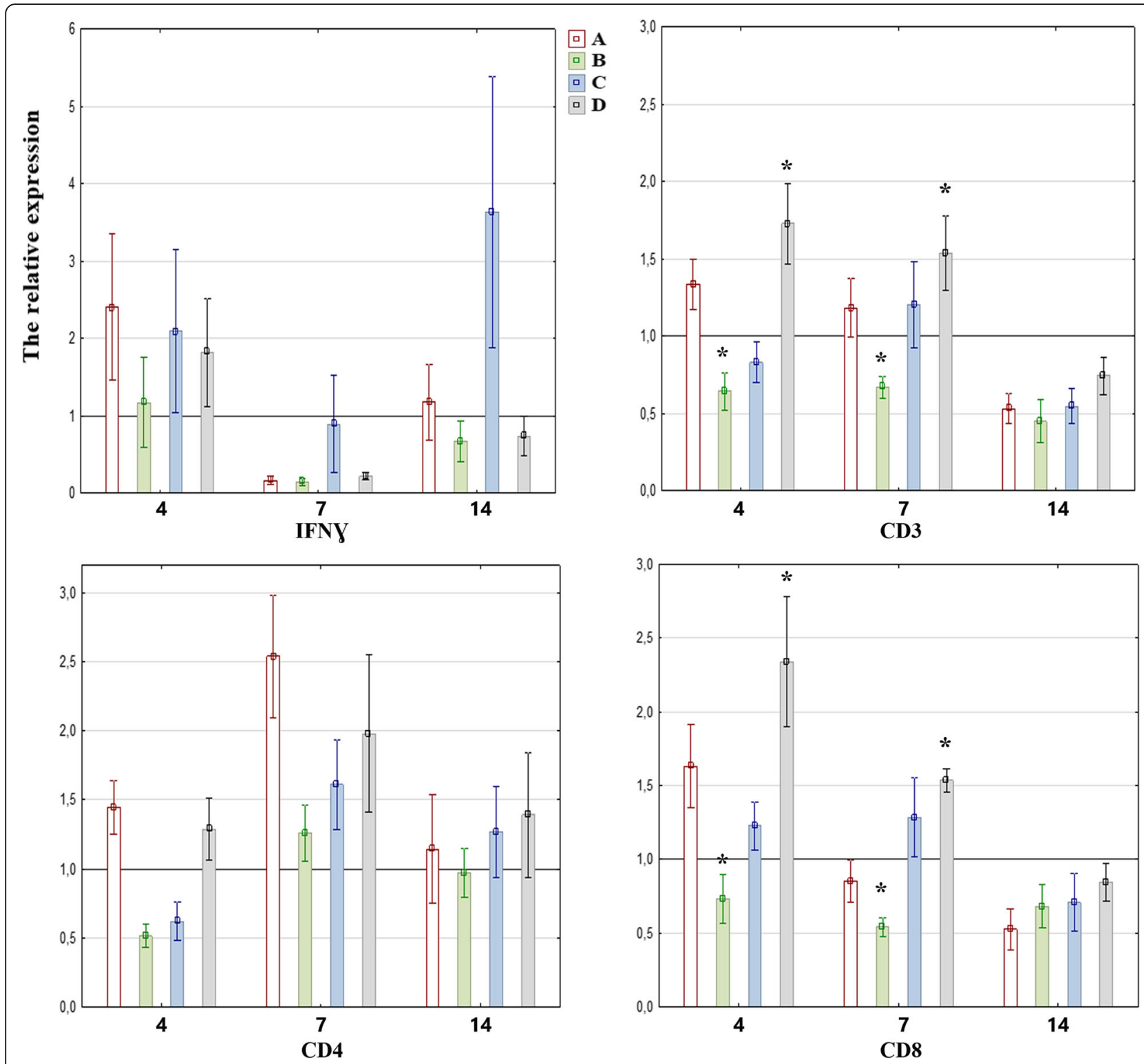

Fig. 1 Mean relative expression of the genes encoding IFN- $\gamma$ and CD3, CD4, CD8 receptors, in splenic mononuclear cells of pigeons administered herbal extracts, at 4, 7 and 14 dpi. The mean relative expression values above 1 (black line) in groups A-D indicate higher gene expression in comparison with the control group (K). The statistical differences between groups are marked with an asterisk. Error bars represent the standard error of the mean

in groups A1 and B1 throughout the entire experiment, and in group D1 at 4 and 14 dpi than in the control group (K1). Group C1 pigeons were characterized by lower expression of the CD3 gene than group K1 birds throughout the experiment, and significantly lower expression of the CD3 gene than group B1 pigeons at 14 dpi $(P=0.006)$ (Fig. 2).

\section{Expression of the CD4 gene}

No significant differences in the expression of the gene encoding surface receptor CD4 in mononuclear cells isolated from spleen samples were observed between pigeons from groups A-D. However, the expression of the above gene in groups A-D was higher than in the control group throughout the experiment. The only exceptions were pigeons from group B at 4 and $14 \mathrm{dpi}$ and pigeons from group $\mathrm{C}$ at $4 \mathrm{dpi}$. The highest number of copies of the CD4 gene in groups A-D were detected at 7 dpi (Fig. 1). A reverse trend was noted in groups A1-D1 where CD4 gene expression was lowest at $7 \mathrm{dpi}$. At $14 \mathrm{dpi}$, the expression of the CD4 gene was significantly higher in group B1 than in group C1 $(P=0.011)$ (Fig. 2). 

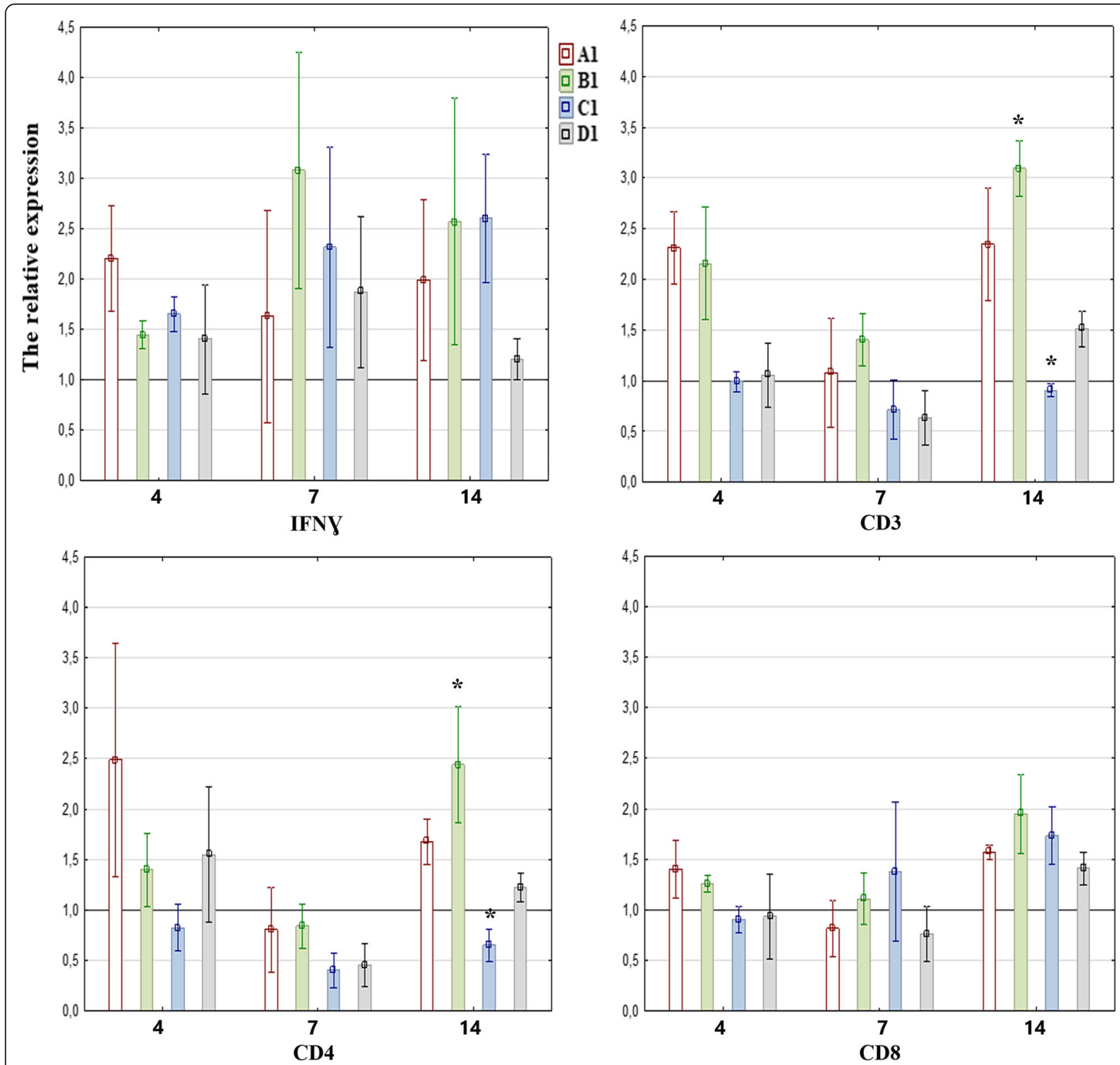

Fig. 2 Mean relative expression of the genes encoding IFN- $\gamma$ and CD3, CD4, CD8 receptors, in splenic mononuclear cells of pigeons inoculated with PPMV-1 and administered herbal extracts, at 4, 7 and 14 dpi. The mean relative expression values above 1 (black line) in groups A1-D1 indicate higher gene expression in comparison with the control group (K1). The statistical differences between groups are marked with an asterisk. Error bars represent the standard error of the mean

\section{Expression of the CD8 gene}

In comparison with group $\mathrm{K}$ pigeons, the expression of the CD8 gene was higher only in groups A, C and D at 4 $\mathrm{dpi}$, and in groups $\mathrm{C}$ and $\mathrm{D}$ at $7 \mathrm{dpi}$. The expression of the CD8 gene was significantly higher in group D at 4 and $7 \mathrm{dpi}$ than in group $\mathrm{B}(\mathrm{P}=0.011$ and $P=0.045$, respectively) (Fig. 1). No significant differences in the number of copies of the CD8 gene were found between infected birds receiving herbal extracts and control group birds, but CD8 gene expression in the above experimental groups peaked at $14 \mathrm{dpi}$ (Fig. 2).

\section{Flow cytometric analysis}

Flow cytometry data are presented in Fig. 3. No significant differences in the percentage of $\operatorname{IgM}^{+} \mathrm{B}$ cells were found between experimental groups or between sampling dates. The highest percentage of $\operatorname{IgM}^{+} \mathrm{B}$ cells was noted at $7 \mathrm{dpi}$ in groups A, B and D (34.4\%, 34.67\% and 37.72\%, respectively). In comparison, in control group birds at 7 dpi, the percentage of $\operatorname{IgM}^{+}$B cells was determined at 28 . $14 \%$ (group K) and $27.23 \%$ (group K1). The percentage of $\mathrm{IgM}^{+} \mathrm{B}$ cells was lowest in groups A1, B1 and C1 at $7 \mathrm{dpi}$ (22.30\%, $24.33 \%$ and $26.05 \%$, respectively) and in groups 

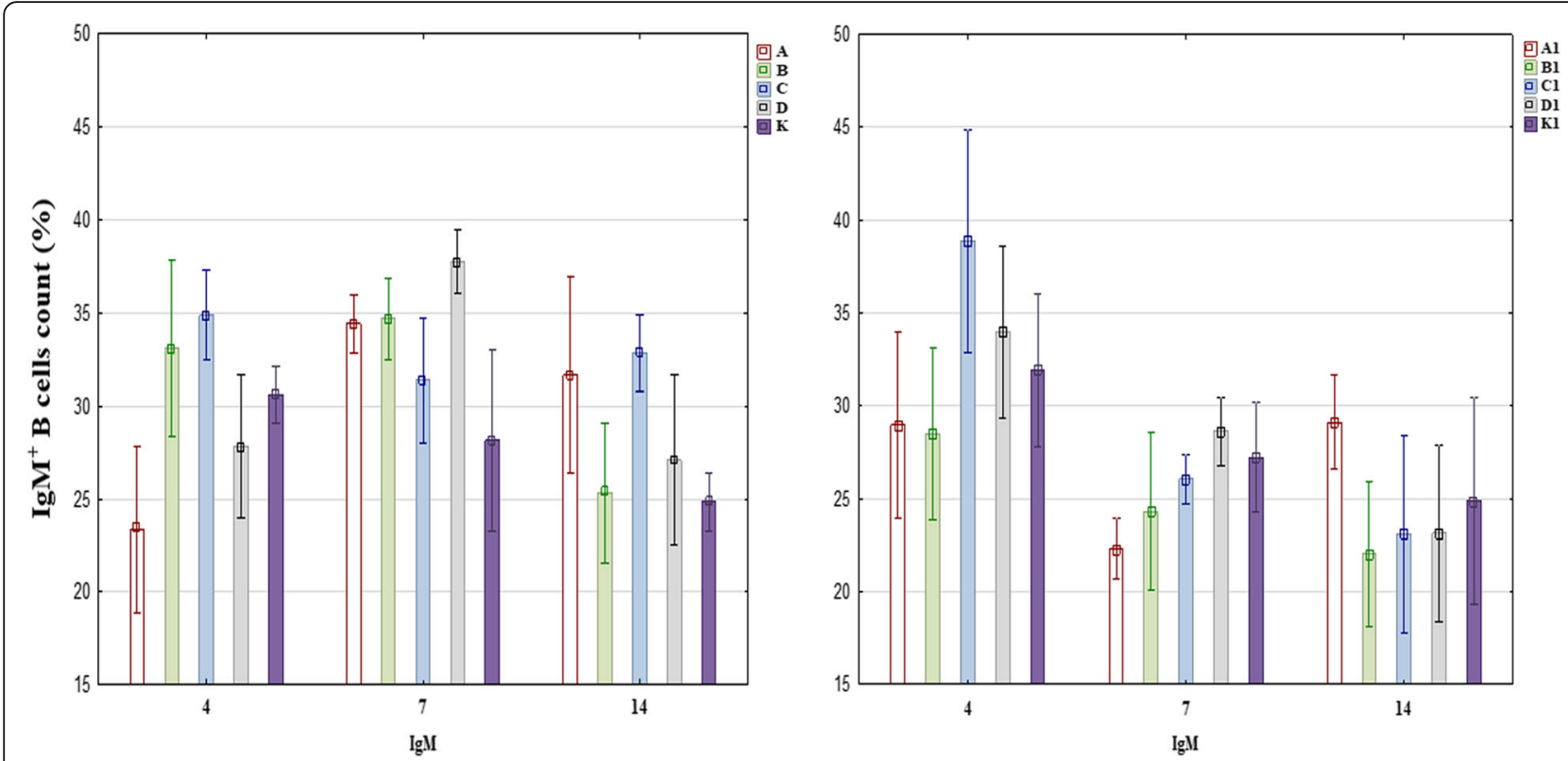

Fig. 3 Percentage of $\operatorname{lgM}^{+} \mathrm{B}$ cells at 4, 7 and $14 \mathrm{dpi}$ in healthy pigeons administered herbal extracts (left) and in pigeons administered herbal extracts and inoculated with PPMV-1 (right)

B1, C1 and D1 at 14 dpi $(22.04 \%, 23.10 \%$ and $23.14 \%$, respectively).

\section{Discussion}

Immunomodulators are biological and synthetic substances which stimulate or suppress humoral and cellmediated immune responses [18]. Antibiotics and synthetic drugs are increasingly replaced by plant-based immunomodulators in the treatment and prevention of animal diseases. Natural materials such as herbs, spices, essential oils and oleoresins are classified as phytogenic feed additives or phytobiotics [4, 44]. Phytobiotics are a rich source of biologically active compounds with a wide range of anti-carcinogenic, anti-inflammatory, antibacterial, antifungal and antiviral properties [17].

Diseases with a viral etiology pose a growing problem in pigeon breeding. This can be attributed mainly to pigeon rearing systems where infectious diseases spread rapidly due to the absence of biosecurity procedures. In view of the above, the present experiment was carried out to demonstrate the immunomodulatory properties of Aloe vera and licorice in the supplementary treatment of viral infections using PPMV-1 as an experimental model. Molecular and flow cytometry analyses were performed on mononuclear cells isolated from the spleen which is the first lymphoid organ to be colonized by pathogenic paramyxovirus strains during infection. [32]. The percentages of $\mathrm{T}$ cell subpopulations were not determined by flow cytometry due to the absence of monoclonal antibodies reacting with pigeon lymphocytes. The investigation conducted previously by Stenzel et al. (2011) with the use of flow cytometry was burdened with high methodological error because commercially available antibodies against chicken lymphocytes are characterized by minimal cross-reactivity with pigeon cells [35]. For this reason, a method for evaluating the expression of genes encoding surface receptors on CD3, CD4 and CD8 T cells was developed in this study as a reliable alternative to flow cytometry.

The results of the conducted research revealed that both herbal extracts had immunomodulatory properties which differed radically depending on the dose and the presence or absence of inoculation with PPMV-1. In uninfected birds, the analyzed herbal extracts stimulated both cell-mediated and humoral immunity, as demonstrated by the higher expression of genes encoding CD4 and CD8 surface receptors in comparison with the control group. The expression of the gene encoding the CD4 receptor peaked at $7 \mathrm{dpi}$ in all birds receiving herbal extracts, in particular in the group administered Aloe vera extract at $300 \mathrm{mg} / \mathrm{kg} \mathrm{BW}$. Similar results were reported by Vahedi et al. (2011) who observed increased proliferation of $\mathrm{CD} 4^{+}$and $\mathrm{CD} 8^{+}$lymphocytes in rabbits receiving Aloe vera extract [43]. Interestingly, the gene encoding receptor $\mathrm{CD} 4$ was least expressed in pigeons receiving the Aloe vera extract at $500 \mathrm{mg} / \mathrm{kg} \mathrm{BW}$ (below control group levels at 4 and $14 \mathrm{dpi}$ ), which indicates that higher doses of the Aloe vera extract deliver immunosuppressive effects. The above phenomenon was also noted in analyses of CMI because the expression of the gene encoding the CD8 receptor was lower in the above group than in the remaining experimental groups 
and the control group. However, the observed differences were significant only relative to group D (licorice extract dose of $500 \mathrm{mg} / \mathrm{kg} \mathrm{BW)} \mathrm{(Fig.} \mathrm{1).} \mathrm{The}$ expression of the gene encoding the CD3 receptor was similar to the expression of the gene encoding the CD8 receptor because the $\mathrm{CD} 3$ receptor is present on all $\mathrm{T}$ cells and, together with the T-cell receptor (TCR), it forms the TCR-CD3 complex responsible for antigen recognition and the transmission of the T-cell activation signal [14]. In view of the above, the increase in the expression of the gene encoding the CD4 receptor or the CD8 receptor should be correlated with a similar increase in the expression of the gene encoding the CD3 receptor. Such a correlation was observed in this study. The decrease in the expression of all analyzed genes at 14 dpi can be attributed to the weakening of immune responses after the elimination of immunomodulatory additives from pigeon diets.

Somewhat different results were noted in pigeons that received immunomodulatory feed additives and were then experimentally infected with PPMV-1. A clear increase in the expression of the gene encoding the CD4 receptor was observed, and it was correlated with an increase in the expression of the gene encoding the CD3 receptor in birds receiving both doses of the Aloe vera extract relative to control group birds and birds receiving licorice extracts. The highest correlation $(P=0.011)$ was noted between groups B1 (Aloe vera dose of $500 \mathrm{mg} / \mathrm{kg} \mathrm{BW}$ ) and $\mathrm{C} 1$ (licorice extract dose of $300 \mathrm{mg} / \mathrm{kg} \mathrm{BW}$ ) (Fig. 2). No such correlations were observed in an analysis of cytotoxic lymphocytes.

The immune response to a viral infection also leads to an increase in the synthesis of interferons which target viruses directly by inhibiting their protein synthesis or indirectly by activating defense mechanisms [41]. In the current study, special attention was paid to the expression of the gene encoding IFN- $\gamma$ because this protein plays a significant role in both immediate and long-term immune responses to a viral infection. IFN- $\gamma$ is produced mainly by $\mathrm{CD} 4^{+}$and $\mathrm{CD} 8^{+} \mathrm{T}$ cells. This cytokine is also secreted by B cells, NK cells, NKT cells and professional antigen-presenting cells [33]. In our study, the expression of the gene encoding IFN- $\gamma$ increased in all birds from the inoculated groups, which can be directly linked with experimental inoculation. Higher expression of the above gene in the groups infected with PPMV-1 and administered herbal extracts than in the control group (K1) could also be attributed to the immunomodulatory properties of Aloe vera and licorice extracts. Similar results were reported by Utsunomiya et al. (1997) in whose study, glycyrrhizin stimulated T cells to produce IFN- $\gamma$ in mice infected with the influenza A virus [42]. In our study, despite an absence of significant differences between groups, the gene encoding IFN- $\gamma$ was most highly expressed in pigeons administered Aloe vera extract at $500 \mathrm{mg} / \mathrm{kg} \mathrm{BW}$, which is partially consistent with the expression of the genes encoding CD3 and CD8 receptors (Fig. 2). The highest expression of the gene encoding IFN- $\gamma$ in group B1 should be associated with the immune response to the viral infection, which was exacerbated by the immunomodulatory effect of Aloe vera extract. The PPMV-1 strain used in the study was pathogenic, and pathogenic paramyxoviruses are most potent in stimulating interferon synthesis [20,24].

The humoral immune response is the last stage of the immune response to an infection, where $M$ class antibodies are produced first and constitute the largest group of immunoglobulins [19]. In the present study, the percentage of $\operatorname{IgM}^{+} \mathrm{B}$ cells was higher in the groups administered both Aloe vera and licorice extracts than in the control groups at $7 \mathrm{dpi}$. However, the noted differences were not significant, probably due to high values of standard deviation (Fig. 3). Therefore, the influence of the tested herbal extracts on humoral immunity could not be confirmed despite the fact an increase in the percentage of anti-NDV antibodies after the administration of Aloe vera extract has been reported by other authors [26]. However, in a study of rabbits, the Aloe vera extract did not influence serum immunoglobulin levels [43], which is consistent with our findings.

\section{Conclusion}

It can be concluded that both Aloe vera and licorice extracts exerted immunomodulatory effects, but their efficacy was clearly correlated with dose and the health status of the analyzed birds. In healthy pigeons, herbal extracts influenced both humoral and cell-mediated immune responses, but the immunostimulatory effects of Aloe vera were observed only in birds receiving a lower dose of the extract. A higher dose of Aloe vera extract exerted immunosuppressive effects on pigeons not infected with PPMV-1, and it exerted immunostimulatory effects on infected pigeons. The above correlations should be taken into consideration during the administration of Aloe vera extracts to birds.

\section{Abbreviation \\ BW: Body weight; cDNA: Complementary DNA; CFU: Colony-forming unit; CMI: Cell-mediated immunity; DPI: Days post-inoculation;

 IgM: Immunoglobulin M; IL: Interleukin; NDV: Newcastle disease virus; PBS: Phosphate-buffered saline; PCR: Polymerase chain reaction; PPMV- \\ 1: Pigeon paramyxovirus type 1; PRR: Pattern recognition receptors; SPF: Specific pathogen free; TLR: Toll-like receptors}

\section{Funding}

This publication was supported by the "Healthy Animal - Safe Food" Scientific Consortium of the Leading National Research Centre (KNOW) pursuant to a decision of the Ministry of Science and Higher Education No. 05-1/KNOW2/2015. 


\section{Availability of data and materials}

The data set supporting the results of this article is included within the article.

\section{Authors' contributions}

DD designed the study, inoculated birds, collected samples, performed PCR, real-time PCR and serological examination, analyzed the data and wrote the manuscript; TS inoculated birds, collected samples and helped to write the manuscript; MŚ and BT participated in sample collection and performed flow cytometry; AK supervised the study and helped to write the manuscript. All authors read and approved the final manuscript.

\section{Ethics approval}

This study was carried out in strict observance of the Act of 21 January 2005 on animal experimentation and the Regulation of the Minister of Science and Information Technology of 29 July 2005 on the National Committee for Animal Experimentation. The research protocol was approved by the Local Ethics Committee on Animal Experimentation of the University of Warmia and Mazury in Olsztyn (Authorization No. 64/2014, valid until 26 November 2017). The researchers made every effort to minimize the suffering of birds.

\section{Competing interests}

The authors declare that they have no competing interests.

\section{Publisher's Note}

Springer Nature remains neutral with regard to jurisdictional claims in published maps and institutional affiliations.

\section{Received: 26 October 2017 Accepted: 20 April 2018} Published online: 02 May 2018

\section{References}

1. Abe N, Ebina T, Ishida N. Interferon induction by glycyrrhizin and glycyrrhetinic acid in mice. Microbiol Immunol. 1982;26:535-9.

2. Ahmed KA, Saxena VK, Ara A, Singh KB, Sundaresan NR, Saxena M, et al. Immune response to Newcastle disease virus in chicken lines divergently selected for cutaneous hypersensitivity. Int J Immunogenet. 2007:34:445-55.

3. Al-Garib SO, Gielkens AL, Gruys DE, Hartog L, Koch G. Immunoglobulin class distribution of systemic and mucosal antibody responses to Newcastle disease in chickens. Avian Dis. 2003;47:32-40.

4. Bampidis VA, Christodoulou V, Florou-Paneri P, Christaki E, Chatzopoulou PS, Tsiligianni T, Spais AB. Effect of dietary dried oregano leaves on growth performance, carcase characteristics and serum cholesterol of female early maturing turkeys. Br Poult Sci. 2005;46:595-601.

5. Cattoli G, De Battisti C, Marciano S, Ormelli S, Monne I, Terregino C, et al. False-negative result of a validated real-time PCR protocol for diagnosis of Newcastle disease due to genetic variability of the matrix gene. J Clin Microbiol. 2009;47:3791-2.

6. Choi S, Chung M-H. A review on the relationship between aloe vera components and their biologic effects. Semin Integr Med. 2003;1:53-62.

7. Dalgaard TS, Norup LR, Pedersen AR, Handberg KJ, Jørgensen PH, JuulMadsen HR. Flow cytometric assessment of chicken T cell-mediated immune responses after Newcastle disease virus vaccination and challenge. Vaccine. 2010:28:4506-14.

8. Darabighane B, Zarei A, Shahneh AZ. The effects of different levels of Aloe vera gel on ileum microflora population and immune response in broilers: a comparison to antibiotic effects. J Appl Anim Res. 2012;40:31-6.

9. Darabighane B, Nahashon SN. A review on effects of Aloe vera as a feed additive in broiler chicken diets. Ann Anim Sci. 2014;14:491-500.

10. Daum I, Finsterbusch T, Härtle S, Göbel TW, Mankertz A, Korbel R, Grund C. Cloning and expression of a truncated pigeon circovirus capsid protein suitable for antibody detection in infected pigeons. Avian Pathol. 2009:38:135-41.

11. Djeraba A, Quere P. In vivo macrophage activation in chickens with Acemannan, a complex carbohydrate extracted from Aloe vera. Int J Immunopharmacol. 2000;22:365-72.

12. Dorhoi A, Dobrean V, Zăhan M, Virag P. Modulatory effects of several herbal extracts on avian peripheral blood cell immune responses. Phytother Res. 2006;20:352-8

13. Dortmans JC, Koch G, Rottier PJ, Peeters BP. A comparative infection study of pigeon and avian paramyxovirus type 1 viruses in pigeons: evaluation of clinical signs, virus shedding and seroconversion. Avian Pathol. 2011:40:125-30.

14. Erf GF. Immune system function and development in broilers. Poultry Sci. 1997:5:109-23.

15. Fiore C, Eisenhut M, Krausse R, Ragazzi E, Pellati D, Armanini D, et al. Antiviral effects of Glycyrrhiza species. Phytother Res. 2008:22:141-8.

16. Guo A, Dongming H, Hong-Bo X, Chang-An G, Zhao J. Promotion of regulatory $T$ cell induction by immunomodulatory herbal medicine licorice and its two constituents. Sci Rep. 2015;5:14046.

17. Hashemi SR, Davoodi H. Herbal plants and their derivatives as growth and health promoters in animal nutrition. Vet Res Commun. 2011;35:169-80.

18. Jantan I, Ahmad W, Bukhari SN. Plant-derived immunomodulators: an insight on their preclinical evaluation and clinical trials. Front Plant Sci. 2015;6:655.

19. Jeurissen SH, Boonstra-Blom AG, Al-Garib SO, Hartog L, Koch G. Defence mechanisms against viral infection in poultry: a review. Vet Q. 2000;22:204-8.

20. Kapczynski DR, Afonso CL, Miller PJ. Immune responses of poultry to Newcastle disease virus. Dev Comp Immunol. 2013:41:447-53.

21. Khattak F, Ronchi A, Castelli P, Sparks N. Effects of natural blend of essential oil on growth performance, blood biochemistry, cecal morphology, and carcass quality of broiler chickens. Poult Sci. 2014;93:132-7.

22. Latheef SK, Dhama K, Samad HA, Wani MY, Kumar MA, Palanivelu M, et al. Immunomodulatory and prophylactic efficacy of herbal extracts against experimentally induced chicken infectious anaemia in chicks: assessing the viral load and cell mediated immunity. Virusdisease. 2017;28:115-20.

23. Liu FX, Sun S, Cui ZZ. Analysis of immunological enhancement of immunosuppressed chickens by Chinese herbal extracts. J Ethnopharmacol. 2010;127:251-6.

24. Liu WQ, Tian MX, Wang YP, Zhao Y, Zou NL, Zhao FF, et al. The different expression of immune-related cytokine genes in response to velogenic and lentogenic Newcastle disease viruses infection in chicken peripheral blood. Mol Biol Rep. 2012;39:3611-8.

25. Livak KJ, Schmittgen TD. Analysis of relative gene expression data using real-time quantitative PCR and the 2 (-Delta Delta C(T)) method. Methods. 2001;25:402-8.

26. Ojiezeh TI, Eghafona N. Humoral responses of broiler chickens challenged with NDV following supplemental treatment with extracts of Aloe vera, Alma millsoni, Ganoderma lucidum and Archachatina marginata. Cent Eur J Immunol. 2015;40:300-6.

27. Perera C, Efferth T. Antiviral medicinal herbs and phytochemicals. J Pharmacogn. 2012;3:45-8.

28. Pestka D, Stenzel T, Koncicki A. Occurrence, characteristics and control of pigeon paramyxovirus type 1 in pigeons. Pol J Vet Sci. 2014;17:379-84.

29. PN-EN ISO 6887-1:2017-1: Microbiology of food and animal feeding stuffs Preparation of test samples, initial suspension and decimal dilutions for microbiological examination - Part 1: General rules for the preparation of the initial suspension and decimal dilutions. International Organization for Standardization. https://www.iso.org/standard/63335.html.

30. Rauw F, Gardin Y, Palya V, van Borm S, Gonze M, Lemaire S, et al. Humoral, cell-mediated and mucosal immunity induced by oculo-nasal vaccination of one-day-old SPF and conventional layer chicks with two different live Newcastle disease vaccines. Vaccine. 2009;27:3631-42.

31. Reynolds DL, Maraqa AD. Protective immunity against Newcastle disease: the role of cell-mediated immunity. Avian Dis. 2000;44:145-54.

32. Rue CA, Susta L, Cornax I, Brown CC, Kopczynski DR, Suarez DL, et al. Virulent Newcastle disease virus elicits a strong innate immune response in chickens. J Gen Virol. 2011:92:931-9.

33. Schroder K, Hertzog PJ, Ravasi T, Hume DA. Interferon-gamma: an overview of signals, mechanisms and functions. J Leukoc Biol. 2004;75:163-89.

34. Shaneyfelt ME, Burke AD, Graff JW, Jutila MA, Hardy ME. Natural products that reduce rotavirus infectivity identified by a cell-based moderatethroughput screening assay. Virol J. 2006;3:68.

35. Stenzel T, Tykałowski B, Śmiałek M, Koncicki A, Kwiatkowska-Stenzel A. The effect of different doses of methisoprinol on the percentage of CD4+ and CD8+ T lymphocyte subpopulation and the antibody titers in pigeons immunised against PPMV-1. Pol J Vet Sci. 2011;14:367-71.

36. Stenzel T, Pestka D. Occurrence and genetic diversity of pigeon circovirus strains in Poland. Acta Vet Hung. 2014;62:274-83.

37. Stenzel T, Tykałowski B, Śmiałek M, Pestka D, Koncicki A. Influence of methisoprinol on the course of an experimental infection with PPMV-1 in pigeons. Med Weter. 2014;70:219-23.

38. Surjushe A, Vasani R, Saple DG. Aloe vera: a short review. Indian J Dermatol. 2008;53:163-6. 
39. Śmietanka K, Olszewska M, Domańska-Blicharz K, Bocian Ł, Minta Z. Experimental infection of different species of birds with pigeon paramyxovirus type 1 virus - evaluation of clinical outcomes, viral shedding, and distribution in tissues. Avian Dis. 2014;58:523-30.

40. Thompson MR, Kaminski JJ, Kurt-Jones EA, Fitzgerald KA. Pattern recognition receptors and the innate immune response to viral infection. Viruses. 2011;3: 920-40.

41. Interferons TSK. Biochemistry and mechanisms of action. Am J Obstet Gynecol. 1995;172:1350-3.

42. Utsunomiya T, Kobayashi M, Pollard RB, Glycyrrhizin SF. An active component of licorice roots, reduces morbidity and mortality of mice infected with lethal doses of influenza virus. Antimicrob Agents Chemother. 1997;41:551-6.

43. Vahedi G, Taghavi M, Maleki AK, Habibian R. The effect of Aloe vera extract on humoral and cellular immune response in rabbit. Afr J Biotechnol. 2011: 10:5225-8.

44. Windisch W, Schedle K, Plitzner C, Kroismayr A. Use of phytogenic products as feed additives for swine and poultry. J Anim Sci 2008; doi: https://doi. org/10.2527/jas.2007-0459.

45. Wise MG, Suarez DL, Seal BS, Pedersen JC, Senne DA, King DJ, et al. Development of a real-time reverse-transcription PCR for detection of Newcastle disease virus RNA in clinical samples. J Clin Microbiol. 2004:42: $329-38$

46. Wolkerstorfer A, Kurz H, Bachhofner N, Szolar OH. Glycyrrhizin inhibits influenza a virus uptake into the cell. Antivir Res. 2009;83:171-8.

Ready to submit your research? Choose BMC and benefit from:

- fast, convenient online submission

- thorough peer review by experienced researchers in your field

- rapid publication on acceptance

- support for research data, including large and complex data types

- gold Open Access which fosters wider collaboration and increased citations

- maximum visibility for your research: over $100 \mathrm{M}$ website views per year

At BMC, research is always in progress.

Learn more biomedcentral.com/submissions 